They warn us, though, that the province's industrial heritage landscape, like the physical remains of the once mighty industries of mining and the railroad, has largely disappeared and is at risk of being lost to public memory. They advise that labour activists and heritage preservationists need to work together to promote an informed public memory of the contributions of working people to society. (91)

Sharon Reilly

The Manitoba Museum, Winnipeg

\title{
Axel Fair-Schulz, Loyal Subversion: East Germany and its Bildbungsbürgerlich Marxist Intellectuals, Berlin: Trafo Wissenschaftsverlag, 2009.
}

It is all too common to see an individual's relations with ideologies and regimes in simplistic terms. This is even more the case when dealing with one of the many sundry "evil empires" that people in the west have heard about in the past hundred years. Thus it is all the more gratifying to read a work as nuanced and sophisticated as Axel Fair-Schulz and his Loyal Subversion: East Germany and its Bildungsbürgerlich Marxist Intellectuals.

In his work, Axel Fair-Schultz goes beyond the conventional stereotypes that so frequently plague the history of German Democratic Republic (DDR). Rather than merely painting a world of loyal regime toadies and noble, if fear full, dissidents, Fair-Schultz examines a much neglected strata. That is those middle class intellectuals who never forsake their belief in socialism, or the hope that the DDR could make strides in that direction. Yet while remaining to this vision, they subverted and subtlety fought against the dogmatism and undemocratic practices of the leaders of East Germany. As the author noted he focused on" the dynamics of this select group of intellectuals' conformity, accommodation, and - albeit limited - dissent with the context of socialist East Germany (1949-1990).” (12)

Admittedly small in number, Fair-Schultz makes a persuasive case that they had a much greater impact than one would first suspect. By doing case studies of three of the most important of these "loyal subversives" - Jürgen Kuczynski (Economic Historian), Hermann Budzislawski (Journalist), and Stephen Hermlin (writer) - this book makes a powerful case that knowledge of the influence of these men is vital if one is to understand the DDR and her history in all its complexity. What emerges clearly, and surprisingly, is that these men despite their at times "Stalinization," managed to "disentangle their Marxist utopianism from the realities of the Soviet bloc, becoming early and effective critics of the deformation of their ideals." (344) 
This is a truly wonderful work that adds the type of texture that is so often missing from historical studies. Of course, it can reasonably be argued that Fair-Schulz may be making too much of a limited sample to make his case. Yet, he argues forcefully to the importance of these individuals not merely as symbols but as significant political and social actors. Moreover, he freely admits the limitations of this first effort when he comments that further research "will produce a more rounded picture of the background, motivations, as well as patterns of thought and behavior of this intriguing group of people." (345) All the same, this is a remarkable book using innovative methodology, solid research expressed in clear prose on a little discussed but vitally important subject. One can only eagerly look forward to this fine scholar's future work.

William A. Pelz

Institute of Working Class History

François Maspero, Out of the Shadows; $A$ Life of Gerda Taro. Translated from the French by Geoffrey Strachan (London: Souvenir Press, 2008).

In this small book, François Maspero has restored Gerda Taro and her stunning photography to view in full light. As Maspero says, he has rescued her from the cruel fate of being always someone else's shadow; never her own. The figure that towered over Taro's life and work is Robert Capa. Probably the finest war photographer of the twentieth century, Capa was Taro's lover, compañero and partner in their commitment as photojournalists to document the horrors of the expanding Nazis movement and the heroism of those who stood against it.

Capa's oft-quoted dictum, that in war photography, if the image is no good the photographer is not in close enough, was one that Taro and Capa lived by. The extraordinary power of the photographic images they produced is proof of their principle: protagonist, photographer and viewer are immersed in the immediacy of the events captured in the picture. Their photographs are a lasting legacy to the Spanish civil war, instantly evoking that conflict. Taro's early pictures are optimistic and memorable: Catalan women undergoing military training on the beach outside Barcelona; the beaming militiawomen off to the Aragon front, in cap and uniform with Sam Browne belt and rifle as they farewell husbands and children. And probably the most famous photograph of the war is Capa's "The Falling Soldier", taken while he and Taro were filming on the Cordoba front in September 1936. The militiaman's head is flung back and the rifle extended away in outstretched arm, he has been caught in the frame at the very point of death. These are the images that signified Republican Spain then and have continued to do so ever since. But of course the other inevitable and terrible side of the Taro-Capa principle of war photography is that it required a 